\title{
Origin of Wild Types and Their Value for Selection of Cultural Potatoes (A Review)
}

\author{
Yu. P. Loginov \\ FSBEI HE Northern Trans-Ural SAU \\ 625003, 7 Respubliki Str., Tyumen, Tyumen Region \\ Tyumen, Russia \\ e-mail: kazaknastenka@rambler.ru
}

\author{
A. A. Kazak \\ FSBEI HE Northern Trans-Ural SAU \\ 625003, 7 Respubliki Str., Tyumen, Tyumen Region \\ Tyumen, Russia \\ e-mail: kazaknastenka@rambler.ru
}

\author{
L.I. Yakubyshina \\ FSBEI HE Northern Trans-Ural SAU \\ 625003, 7 Respubliki Str., Tyumen, Tyumen Region \\ Tyumen, Russia \\ e-mail: kazaknastenka@rambler.ru
}

\begin{abstract}
The largest discovery of C. Columbus is not only the continent of America, but also the potato culture, which later became the main food of the population around the globe. South America is the primary genetic center of origin for many potato species. Wild species were formed here during the landscape change. They have the genes of resistance to stress factors: drought, low temperatures, diseases, pests. Some species are characterized by high protein content and other biochemical parameters. The cultural potato species (Solanum Tuberosum) came a long evolution under the human influence. Economic features were improved, mainly through intraspecific hybridization. At the same time, the productivity and quality of tubers were significantly improved. In addition, at the first stage of selection, a certain progress was demonstrated in the creation of disease-resistant varieties, but as they were used in production, more aggressive races of pathogens appeared and began to affect potato crops. In recent decades, many registered potato varieties have been affected by several diseases. All this has led to the use of a large number of chemical plant protection products, which are not safe for the environment and human health. The radical solution of the mentioned problem is the creation of diseaseresistant potato varieties. At the same time, as a starting material it is advisable to use the priceless wealth of wild potato species collected in the 1920-1930s of the past century by N.I. Vavilov, S.M. Bukasov, V.S. Yuzepchuk, and later by P.M. Zhukovsky, L.E. Gorbatenko and others. During the past and the beginning of the present centuries not more than ten wild cultural types of potatoes were used in breeding, which allowed solving a number of key problems. More than 200 wild species remained unaffected in breeding programs. The value of wild species for breeding, depending on the geography of their origin, is described in this paper. Over the past 100 years such sciences as genetics, cytology, physiology, biochemistry, and plant protection have been successfully developed thus forming a theoretical basis for selection. An integrated approach to further study of wild potato species will make it possible to fully reveal their value for breeding of cultivated potatoes.
\end{abstract}

Keywords-potato; origin; species; valuable features

\section{I.INTRODUCTION}

The origin of potatoes is connected with the formation of non-tropical flora of South America [1]. According to E.V. Vulf [2], before the elevation of the Andes the non-tropical flora dominated in tropical South America. Its origin is attributed to the period of formation of elevated uplands of Guiana and Brazil during the Mesozoic era [3]. During this period the sea was still stretching on the place of the Andes, therefore the flora of the Andes is much younger. The mountain ridge began to form at the end of the Cretaceous era (about 100 million years ago) and continued until the end of the Tertiary period when the mountains almost reached their present height. The mountains are still being formed in this region. This is evidenced by a recent earthquake in Peru (1970) and the Ruiz volcanic eruption in Colombia (1986) [4].

The examples of the fact that the flora of tropical American savannas originates from the flora of moist tropical forest resulting from the change of soil and climatic conditions include potatoes, ullucus and oxalis. According to E.V. Vulf [2], the Solanum species were especially developed in the tropics of the New World. The Petota Dumort (Tuberarium Dun), which includes tuberiferous plants, is divided into several groups illustrating the appearance of xerophytic tuberiferous forms from initial forest hygrophytic types. For instance, these include the series of species united in subsections Basarthrum Bitt (Caripensa Corr.), Estoloniferum (Buk.) Gorbat. The above species include plants with ligneous, climbing or upright stems up to $3 \mathrm{~m}$ high and above, which generally do not form tubers. The mentioned plant species grow in rainforests of Venezuela, Colombia, Ecuador, Peru, Chile and Central America [5].

Those are followed by Chomatophila, Conicibaccata, Piurana, Minutifoliola and some other series presented by species with herbaceous stems, characterized by poor tuber formation or lack of any kind. These are mainly the representatives of forest formations of the equatorial part of South America. Obviously, these forest species, rising in higher 
vegetable layers, have given rise to tuberiferous xerophytic potato species of dry highlands in Peru, Bolivia and Argentina (Acaulia, Cuncoalata, Bukasoviana, Megistacroloba series), i.e. areas, which turned into a desert with the elevation of the Andes. Certain species appeared in a desert zone of the Pacific coast (Vaviloviana, Bukasoviana series - Collina subseries) and are content only with the moisture of seasonal fogs [5].

Some xerophytic species raised towards the high-mountain belt of the Andes thus reducing temperature to $-8{ }^{\circ} \mathrm{C}$ (S. acaule), or extended northwards and southwards as weeds (Megistacroloba and Bukasoviana series) along the ridge of the continent; others evolved in lowlands of the Pacific (Maglia and Tuberosa series) and the Atlantic (Commersoniana series) coasts and at small heights of southeast piedmont slopes of the Andes - in the zone of cool dry (Tarijensia series) and rain (Vungasensia series) forests or in arid lands of Chako (Glabrescentia series).

It is found that wild tuberiferous tubers diploid species, which remained until now, represent the first evolution stage of tuberiferous forms of the Solanum species. Spontaneous crossbreeding of these species, introgression, mutation and heterosis led to the appearance of three-, tetra- and pentaploid species with a variety of agronomic features suitable for direct consumption or use in breeding programs [6].

It should be noted that there is an abundance of naturally occurring wild potato species, many of which were eaten and are still eaten by aborigines. It makes it possible to assume that not even one but many of them were introduced into culture by a primitive man.

\section{II.RESULTS AND DISCUSSION}

The breeding of cultural potatoes (Solanum tuberosum) was conducted within 300 years generally by selection and hybridization of the above species. The initial stage of intraspecific hybridization demonstrated obvious improvement of economic features. A large number of high-yield potatoes with good and excellent taste of potato tubers was created, many of which were characterized by high ecological plasticity, stability, occupied big acreage and were cultivated over a long period. These include Lorkh, Gatchinsky, early Priyekulsky, Stolovy 19, Nevsky, etc. [7].

It should also be noted that new diseases and pests have appeared, race composition of earlier known diseases strongly damaging register and newly created potato species has changed over such a long period of cultural potatoes cultivation. There is a need for new genes therefore breeders and geneticists started to use wild potato species more often in their studies. This priceless heritage that includes 260 species was collected in nature and left to future generations by N.I. Vavilov [1], S.M. Bukasov by [3], S.V. Yuzepchuk [8], P.M. Zhukovsky [9], A.G. Zykin [10], L.E. Gorbatenko [4], G. Bitter [11], J. Hawkes [12], D. Correll [13], C. Jchoa [14], and K. Okaola [15].

For the first time N.I. Vavilov [1] proposed that South America - the homeland of potatoes - is rich in initial material for the breeding of this culture. In 1925, together with employees of the N.I. Vavilov Research Institute of Plant Genetic Resources (VIR) S.M. Bukasov and S.V. Yuzepchuk he launched the first expedition to collect wild species. In 1932, N.I. Vavilov visited several countries of Latin America. In total about 60 wild species and 20 primitive cultural species cultivated by Indians were discovered and described during these expeditions [4].

N.I. Vavilov's expeditions provoked an interest in wild potato species and resulted in a series of expeditions by foreign researchers. From 1930 to 1939 scientists of Germany, Sweden, England and the USA also held a number of expeditions.

Later VIR employees went on expeditions to South and Central America, which allowed creating a globally important collection of wild potato species. It is the most valuable property of the country. It is a reliable resource for successful solution of the food security task in the country and the world in general in the near and long-term future.

A wide range of biological and agronomic features of wild and cultivated potato species, which present the greatest interest for breeding industry, is caused by a variety of environmental conditions in areas of their growth. For example, such species as S. acaule, S. bukasovii, S. megistacrolobum mostly resistant to low temperatures $\left(-8 /-10{ }^{\circ} \mathrm{C}\right)$ grow in cold mountain regions of Peru, Bolivia and Argentina. The above species stretch vertically to the heights of 4000-4500 m and more above sea level thus reaching the permanent snow cover. Cold-hardy species are distinguished by rosette-like bushes pressed to the ground, which form remains unchanged during the entire vegetative period. They are characterized by short flower stalk, high concentration of highly soluble sugars in leaves, which is higher than for other species, and thickness of a leaf blade [4].

It is found that heat- and drought-resistant potato species most often grow in hot and arid climate [16]. The most heatresistant potato species are as follows: S. maglia, S. kurtrianum, S. catarthrum [17].

Depending on climatic conditions of the area of some wild potato species in South America the following may be used in selection for drought resistance: S.chacoense, S. commersonii, S. calvescens, S. tarijense, S. infundibuliforme, S. oplocense, S. kurtrianum, S. spegazzinii, S. maglia. The majority of the above species grows on dry plateaus or mountain slopes of southern Bolivia and northwest Argentina [3]. The maternal tuber of drought-resistant potato species remains for quite a long time. H. Ross divides drought-resistant potato species into two groups: with normally developed and with very small leaf blades. The first group includes S. tarijense, S. gandarillasii, S. pampasense, S. kurtrianum, S. sandemanii, S. acaule subsp aemulans, S. ochoae. These species are more suitable for drought resistance selection than the second group, which includes S. gracilifrons, S. spegazzinii, S. infundibuliforme, S. xerophyllum, S. Gourlayi [5]. Many xerophytic Solanum species combine drought resistance with resistance to such diseases as scab, wart and nematode.

The Colorado beetle causes the greatest damage to potato farming in the world [18]. The homeland of the Colorado beetle is North America [19]. For the first time it was discovered in 
1923 in the USA near the Rocky Mountains where it was fed by various wild plants of the solanaceous family. With the introduction of potatoes in the central states of North America (Colorado, etc.) the Colorado beetle shifted from wild plants to potatoes. Since then it expanded and quickly developed new territories in different countries of the world.

However, the Colorado beetle is still absent in South America and hence the most resistant potato species are present in the south of wild potato regions.

The studies by A.Ya. Kameraz, V.V. Olefir, J. Scholk et al., S. Sinden et al., M. Timonin, etc. [20] showed that Glabrescentia (S. chacoense), Megistacroloba (S. megistacrolobum, S. boliviense, S. raphanifolium), Tarijense (S.tarijense, S. berthaultii), Yungasensia (S. yungasensa), Bukasoviana (S. Kurtzianum) species are the most promising for selection on resistance to Colorado beetle. They naturally grow in the mountains of Bolivia, Argentina and La Plata lowland.

In the last decades, a new pest - potato root nematode (Globodera rostochiensis and Globodera pallida) - appeared in many regions of the country. It decreases the productivity by $30-50 \%$ and more [21]. The center of origin of different types of nematodes is within the territory limited to Peru-BoliviaArgentina triangle [4]. As a result of joint evolution of plants and the generating pathogens new potato species resistant to them were formed here. First of all this includes S. vernei (resistant to all types of nematodes - gall, stem, cyst), S. tarijense, S. chacoense, S. speggazinii, S. kurtzianum, S. sparsipilum (resistant to gall, cyst nematodes), $\mathrm{S}$. megistacrolobum, S. boliviense, S. famatinae, $\mathrm{S}$. simplicifolium, S. bukasovii, S. catarthrum (resistant to stem and cyst nematodes widespread in our country).

Viral diseases quickly worsen potato species especially in dry and hot regions. However, registered potato species strongly differ in resistance to viruses, i.e. good results may be achieved through selection $[22,23]$.

A large number of potato species having resistance genes to numerous viral disease excitants were revealed in South America [24]. Their greatest concentration is in the South of Peru, Bolivia and the northwest regions of Argentina. They are presented here by Bukasoviana (S. vernei, S. kurtzianum, S. gourlayi, S. mochiguense, S. leptophyes, S. sparsipilum, S. bukasovii, S. catarthrum, S. setulosistylum, S. sucrense); Megistacroloba (S. megistacrolobum); Tarijensia (S. berthaultii, S. Tarijense); Simpliciora (S. microdontum); Andigena (S. curtilobum, S. phureja); Yungasensia (S. yungasense). The areas of only some of them stretch beyond the specified region occupying more extensive territories of the Andes (S. acaule, S. andigenum), La Plata lowland (S. chacoense, S. commersonii) or the Pacific coast (S. maglia, S. leptosigma, S. Tuberosum var. Chiloense) [5].

Bacterial wilt or brown stem rot caused by bacterium Pseudomonas Solanacearum harm potato farming a lot [25]. According to the International Potato Center [25], the samples mostly resistant to diseases are typical for S. phureja (S. rybinii) from Colombia.
Scientists from the Department of Genetics of the Central Research Institute of India [25] identified a clone (SS 529-1) resistant to pathogen via artificial infection from $\mathrm{S}$. microdontum samples, which grows in warm valleys of the northwest provinces of Argentina (Jujuy, Salta) and the southeast of Bolivia (Santa-Cruz) where it rains within 7-9 months a year [4].

C. Ochoa and P. Schmidiche [26] report that they found samples resistant to bacterial wilt among populations of $\mathrm{S}$. rybinii, S. sparsipilum, S. chacoense.

The black stem belongs to dangerous potato diseases. N.Ya. Chmora and V.V. Arnautov [27] noted that the black stem is widespread in mid- and northern zones of the European part of Russia and Siberia. Soon after, this disease was recorded in other regions of the country. The Pectobacterium phytophtorum (Appel) is the excitant of the black stem and the soft rot diseases [28].

Humid and cool climate provokes the development of the black stem excitants. The greatest concentration of species resistant to the specified pathogen is observed in Bolivia and northwest Argentina [5]. According to M.I. Koromyslova [29], N.M. Vlasov, L.N. Bushkova, D.S. Pereverzev [30] and I. D. Kogut [31], the resistance to the black stem disease is revealed among S. tarijense, S. berthaultii, S. microdontum, S. simplicifolium, S. megistacrolobum, S. raphanifolium, S. toralapanum, S. acaule, S. vernei, S. catarthrum, S. sucrense.

Samples resistant to the black stem are also present within the following cultural species: S. rybinii, S. phureja, S. andigenum. The piedmont regions of Argentina and La Plata are characterized by resistant species of $\mathrm{S}$. chacoense and $\mathrm{S}$. commersonii, and on the Pacific coast of Chile - among populations of S. maglia, S. molinae, S. Tuberosum var. chiloense.

The potato blight appears in wet years, which is prokoved by Phytophthora infestans (Mont.) de Bary. A radical way to fight against the above disease is to create resistant species. Wild potato species, which grow in Mexico, present an exclusive interest as initial material in the solution of the mentioned problem. Favorable climatic conditions for excitants contribute to reproduction and appearance of new more aggressive pathogen races and resistant potato forms [32]. The following species shall be noted: Conicibaccata (S. colombianum, S. santolallae, S. violaceimarmoratum), Yungasensia (S. yungasense), Circaeifolia (S. capsicibaccatum), Andigena (S. andigenum).

According to N.M. Zoteeva and L.M. Turuleva [33], the majority of samples resistant to phytophtore are concentrated in Bolivia: S. berthaultii, S. capsicibaccatum, S. simplicifolium, S. microdontum, S. vernei. The resistance of the above types to phytophtore is critical since they are phylogenetically closer to cultural potatoes and from them it is easier to transfer genes controlling resistance to selection variety.

The black scab of potatoes (Rhyzoctonia solani Kuhn activator) is among the most harmful and widespread potato 
diseases. It causes the greatest damage in areas with cold springs in northern and middle parts of Russia [34].

The following potato species are interesting in terms of selection on resistance to the black scab: S. vernei, S. kurtzianum, S. Sanctae-rosae, S. tarijense, S. oplocense, S. gourlayi, S. boliviense, S. megistacrolobum, S. vidaurrei, S. simplicifolium, etc. [35, 36, 37]. Their areas cover the south of Bolivia and the northwest regions of Argentina [38].

The brown scab caused by fungus strains of Streptomyces scabies (Thaxter) Waksman et Henrici is a permanent potato disease. It is often present in tubers to a larger or smaller extent. The selection breeder shall be very careful with parental forms in order to get resistant species, thus mainly focusing on wild potatoes.

The areas of potato species, which include scab-resistant forms, are typical for cool $\left(12-18{ }^{\circ} \mathrm{C}\right)$ forest formations with acidosis soils (for powdery scab) or with faintly alkaline reaction (for brown scab). According to H. Ross [39], scabresistant species are found in droughty regions of Bolivia and Argentina. He believes that such diseases are caused by parasites of dry soils. According to other scientists - V.V. Sergeyev, A.Ya. Kameraz, A.S. Filippov and Z.G. Ivanchenko, D. Reddick, L.A. Dionneetal, the greatest number of forms resistant to one or both scab types is present among mountain types: Acaulia (S. acaula) Subacaulia (S. xcurtilobum), cultivated species: S. phureja, S. andigenum, S. goniocalyx, wild populations: S. vernei, S. catarthrum, S. sparsipilum, S. kurtzianum occupying dry mountainous regions stretching from the Central Peru to northwest Argentina, as well as among S. chacoense and S. commersonii present in dry foothills and valleys of Chako [4].

\section{III.CONCLUSION}

The review does not cover the full list of potato economic features, which shall be considerably improved in the near and long-term future. Wild potato species represent an invaluable resource for the solution of tasks related to the selection of cultures at present.

Conclusions. For over 300 years, potato has been considered the main food in many countries of the world. It will remain such in the future.

Among 260 known species, the Solanum tuberosum gained the greatest popularity. Through its use it evolved a lot under the human influence. The breeding was generally conducted by intraspecific hybridization. Many economic features (productivity, form and taste of tubers, their biochemical indicators, etc.) were massively improved in comparison with similar species. Besides, certain features, especially resistance to diseases, pests and other stressors, remained at the same level and were considerably deteriorated.

Long-term cultivation of potatoes causes the appearance of aggressive races of the known diseases. Besides, new pests and diseases of this culture spread very quickly. They reduce productivity and quality of potato tubers.

The selection within Solanum tuberosum has generally exhausted its potential. This led to a wide use of chemical crop protection products. The excessive use of the above means has a negative influence on the environment and human health.

The radical solution of the mentioned problem is the creation of disease- and pest-resistant potato varieties. This problem may be solved through the widespread use of wild potato species having valuable genes as initial materials. The use of certain wild potato species in selection in the past and the beginning of the present centuries confirms high efficiency of this trend. In this regard, there is a need to pay tribute to a great scientist N.I. Vavilov and his students S.M. Bukasov, S.V. Yuzepchuk, P.M. Zhukovsky, A.G. Zykin, L.E. Gorbatenko, etc., which opened the centers of potato origin, collected, studied and developed domestic and world selection of wild potato species. Such a powerful genetic resource of the VIR collection makes it possible to look ahead with confidence.

The discovery of potato species diversity in our country and the world in general led to interspecific hybridization in order to create new species with economic features unknown in the world practice of potato farming: late blight resistant variety, cold-hardy species, high-starch species, short duration variety $[1 ; 20 ; 41]$.

The Institute of Potato Economy and the Belarusian Experimental Selection Station (former) introduced late blight resistant varieties: late blight resistant variety 8670 , Moscovsky, Agronomichesky, Trudovoy species received through crossbreeding of cultural varieties with Mexican species S. demissum. The same institute obtained high-yield and late blight resistant hybrids from repeated crossbreeding with another Mexican type S. semidemissum.

Cold-hardy, high-yield species were obtained through crossing of S. tuberosumc S. Schreiteri at the Potato Pilot Station in Ulyanovsk. The N.I. Vavilov Research Institute of Plant Genetic Resources in St. Petersburg managed to create such late blight and wart-resistant species and hybrids as Kameraz 1, 2, 3, 4, Uralsky, Krasnoufimsky and others mainly through crossing of S. tuberosum with S.demissum. I.A. and M.N. Veselovskys created high-yield species with early tuber formation: Imandra, Umptek, Marnikva, Polar rose, Khibiny 3, early Khibinsky through interspecific hybridization at the Polar Experimental Station of the All-Union Institute of Crop in Khibiny [20].

In recent decades the N.I. Vavilov Research Institute of Plant Genetic Resources jointly with research and higher educational agricultural institutions of the country intensified the selection of potatoes via interspecific hybridization. The Northern Trans-Ural State Agricultural University (Tyumen) closely cooperates with the Laboratory of Interspecific Potato Hybridization of the N.I. Vavilov Research Institute of Plant Genetic Resources.

Remote hybridization of potatoes is widely applied by selection breeders and geneticists of the Lorch Potato Research Institute. The same institute cooperates with the Northern Trans-Ural State Agricultural University, thus the selection and assessment of advanced materials is carried out in several ecological and geographical points of the Tyumen region. The first joint species of potatoes are being prepared for the state 
variety trials. According to competitive variety trials in the pilot field of the Northern Trans-Ural State Agricultural University the perspective selective potato species are able to compete with foreign selection species, and in terms of their resistance to diseases and other stressful factors have indisputable advantage compared to the latter ones. All this contributes to successful solution of the import substitution problem in the near future.

The scientists of the Leningrad base station of the Institute of General Genetics, and later the Northwest Research Institute of Economy and Agriculture (Belogorka village, Gatchinsky district) were quite successful in remote hybridization. Moreover, Nina Aleksandrovna and Alexander Alekseyevich Lebedevs who successfully developed the theory of remote hybridization and applied this method in practical selection have worked here since 1948. After the death of these prominent scientists their studies were continued by their daughter Vera Aleksandrovna Lebedeva. Thus, the Lebedev dynasty has been developing the method of remote hybridization of potatoes within 70 years. The study of the Lebedevs resulted in over 20 species of potatoes, which successfully passed the state variety trials and are included in the register of selection inventions of various regions of the country and are approved for use in production. They cover hundreds of thousands of hectares in different regions of the country.

The species have valuable genes of various economic features. According to early ripening they refer to different groups. Thus, the early ripening species include the following: Red and White spring. Bullfinch, Lark, League, Charoite; the middle-early ripening species - White night, Oredezhsky, Wizard, Fairy tale, Inspiration, Scarlet sail, Danaya, Pearl; the mid-season varieties - Hybrid 390, Naiad, St. Petersburg mystery, Charm, Lilac fog, Russian beauty, Hussar. Let us briefly describe the economic features of some potato species.

The Spring variety with red coloring of tubers is obtained from crossing of three species - S.demissum, S.stoloniferum and S. tuberosum. Ultra-early, late blight resistant and highyield varieties. In Western Siberia the first potato unearthing of the Spring variety gives $130-140 \mathrm{c} /$ hectare and exceeds all species of the above group of ripeness in productivity. By August 20 the grade reaches its economic ripeness and gives $350-400 \mathrm{c} /$ hectare. The tubers are attractive and have high purchasing power.

The ultra-early ripening species also include Charoite - a 5specific hybrid obtained with S. berthaultii, S. stoloniferum, S. demissum, S. andigenum, S. tuberosum. During early harvesting period it is characterized by high marketability and forms large, flat, yellowish tubers with superficial buds. At the same time even early harvested tubers have excellent taste. The variety is a large yielder $-410-460 \mathrm{c} /$ hectare, it is plastic, shows good results both in droughty and wet years.

The Bullfinch variety is a 6-specific hybrid obtained with S.vernei, S. phureja, S. olemissum, S. stoloniferum, S. andigenum, S. tuberosum. The variety is high-yielding, the marketability of tubers makes $90 \%$, it has an excellent taste, good keeping capacity, starch concentration in tubers makes up to $20 \%$.
The Bullfinch is resistant to wart, frost, brown scab and viral diseases. It is quite late blight resistant regarding tubers and tops. It is included into the register of selection inventions and approved for use in production in 9 regions of the country.

The Wizard is a 3-specific hybrid obtained with S.vernei, S. phureja, S. tuberosum. It is middle-early, productivity makes $420-490 \mathrm{c} /$ hectare, starch concentration is $18-22 \%$, excellent taste. It is resistant to wart and viroid, highly late blight resistant, drought- and overwetting-resistant. It is included into the register of selection inventions and approved for use in production in 7 regions of the Russian Federation.

Other selection varieties of the Northwest Research Institute of Economy and Agriculture are characterized by a set of valuable economic features and are successfully grown in different regions of the country thus demonstrating high economic efficiency.

\section{References}

[1] N.I. Vavilov Five continents. Moscow: Geography, 1962, pp. 255.

[2] E.V. Vulf History of florae of the globe. L., 1944, pp. 580.

[3] S.M. Bukasov Wild types of potatoes. Cultural flora of the USSR. L., 1971. vol. 9, pp. 5-40.

[4] L.E. Gorbatenko Types of potatoes of South America. Sankt-Petersburg, 2006, pp. 455.

[5] L.E. Gorbatenko Wild types of potatoes of Colombia and Venezuela. Works on applied botany, genetics and selection, 1980, vol. 66, iss. 2, pp. 122-130.

[6] K.Z. Budin Wild types of potatoes as donors are steady against pathogens. Works on applied botany, genetics and selection, 1987, vol. 115, pp. 718.

[7] A.V. Korshunova Potatoes of Russia. Moscow: VNIIKKh Publ., 2003. vol. 2, pp. 472.

[8] S.V. Juzepchuk New types of the sort Solanum from the Tuberarum Dun group. ANSSSR Publ., Biology, 1937. no. 2, pp. 295

[9] P.M. Zhukovskij World vegetable resources on service of the Soviet selection. M.; MSH SSSR Publ., 1957, pp. 16.

[10] A.G. Zykin Chile-gencentre of potatoes. Messenger of agricultural science, 1970, no. 30, pp. 124-125.

[11] G. Bitter Solana nova vel minus cognita. Fedde Report. Spec. Novarum Regni Ved., 1912-1914. No. 10-13, pp. 566.

[12] J. G. Hawkes History of the potato. The potato crop: the scientific basis for improvement. Chapman and Hall. London, 1978. Chapter 1, pp. 1-14.

[13] D. Correll The potato and its wild relatives. Texas Research Foundation. Ronner. Texas, 1962, pp. 606.

[14] C. Ochoa The potatoes of Bolivia. South America. Cambridge University Press, 1990, pp. 512.

[15] D. Shpaar, Potatoes: cultivation, cleaning and storage. Moscow: DLV Agrodelo, 2007, pp. 434.

[16] K.A. Okada Collection and taxonomy of the Argentine tuberbearing Solanums. Report of the Planning Conference on the Exploration, Taxonomy and Maintenance of Potato Germ Plasm. III. Peru, Lima, CIP, 1979, pp. 193.

[17] T.L. Gautney, F.L. Haynes Recurrent selection for heat tolerance in diploid potatoes (Solanum tuberosum Subsp. phureja and Stenotonum). Amer. Potato J., 1983. vol. 60. no. 7, pp. 537-542.

[18] Ju.P. Loginov, A.S. Gajzatulin, V.A. Krasnopjorov, I.A. Myshkin “Crop yield and quality of potato tubers resistant to Colorado beetle in woodlands of Tyumen region," Proceedings of the II International student scientific and practical conference 'Urgent probkems of science and economy: new challenges and solutions', 2018, pp. 78-81. 
[19] R.G. Krasnoshtejn Study of a collection of potatoes in the conditions of the semi-desert Northern Priaralya, Extended abstract of Cand. Sci. (Agriculture) Dissertation. L., 1968, pp. 24.

[20] S.M. Bukasov, A.Ja. Kameraz, Bases of selection of potatoes. M.; L.: Sel'hozgiz, 1959, pp. 528.

[21] A.Ja. Kameraz, G.M. Najdanova, Fight against viral diseases of potatoes by creation of steady grades. Moscow, 1978, pp. 51-52.

[22] S.M. Bukasov, L.I. Kostina, Fight against viral diseases of potatoes by creation of steady grades. Fourth congress of the all-union meeting on genesis and selection named after N.I. Vavilov, Kishinjov, 1982. Part 2, pp. 70.

[23] Y.P. Loginov, A.A. Kazak, L.I. Yakubyshina, T.N. Falaleeva, S.N. Yashchenko, E.T. Yarova, Breeding value of collection varieties of potato in the forest-steppe zone of the Tyumen region. Journal of Pharmaceutical Sciences and Research, 2018. vol. 10. no. 1. pp. 377-380.

[24] A.V. Butov, A.A. Mandrova, Harvest, quality and safety of potatoes when using regulators of growth of plants. Engineering and technology of food production. 2017. no. 2. pp. 13-19. DOI 10.21179/2074-9414-2017-213-19.

[25] N.F. Byvako, Cultural types of potatoes of South America, their area and value for selection. Works on applied botany, genetics and selection, 1982. vol. 73, iss. 2. pp. 91-96.

[26] H.D. Thurston, E. Smith, Testing the Colombian potato collection for resistance to PS. Solanacearum. Am. Potato J., 1965. vol. 42. pp. 298.

[27] C. Ochoa, The potatoes of Peru. At the same place, 1999, pp. 550.

[28] B.N. Dorozhkin, Selection of potatoes in Western Siberia. Omsk, 2004, pp. 272.

[29] S.D. Kiru, Historical and contemporary significance of world collection of potato at the All-Russia Research Institute of Plant Breeding. Problems of systematics and potato breeding. Saint Petersburg, 2016, pp. 11-12.

[30] C.G. Dzhioeva, S.S. Basiev, F.T. Gerieva, M.A. Gerieva, Use of a biodiversity of early ripe grades of potatoes in selection. New technologies. 2017. no. 3. pp. 81-87.
[31] I.D. Kogut, Test of cultural types of potatoes and their hybrids to bacterial diseases. Potato selection, 1985, pp. 65-74.

[32] E.A. Simakov, V.I. Starovojtov, B.V. Anisimov, Potatoes industry. Moscow: NPF AgroNif, 2013, pp. 273.

[33] K.Z. Budin, Genetic bases of creation of donors of Solanum L. SPb: VIR, 1997, pp. 40.

[34] A.V. Butov, A.A. Mandrova, Organic potatoes for baby and dietary food. Equipment and technology of food production. 2015. no. 3, pp. 121-126.

[35] A.Ju. Prosekov, Hunger retrospectives: lessons of the past and calls of the future. Equipment and technology of food production. 2017. no. 4, pp. 5-20. DOI 10.21603/2074-9414-2017-4-5-20.

[36] A.P. Ermishin, Genetic features of allotetraploid wild potatoes (Solanum) as a selection object. Messenger of the National Academy of Sciences of Belorussia, Biology. vol. 63, no. 1. 2018. DOI: http://dx.doi.org/10.29235/1029-8940-2014-0-1-23-31.

[37] D.I. Eremin, Changes in the content and quality of humus in leached chernozems of the Trans-Ural forest-steppe zone under the impact of their agricultural use. Eurasian soil science. 2016. vol. 49. no. 5, pp. 538-545. DOI: 10.1134/S1064229316050033.

[38] A.A. Lebedev, Selection of potatoes on resistance to a rizoktoniya (Rhizoctonia solani Kiihn)]. LSHI, 1968. vol. 124. iss. 2. pp. 16-24.

[39] H. Ross, Ausgangsmaterial fiir die Ziichtung. Rn: Kappert H. and Rudorf W. Hand buch der Pflanziichtung. 2 Aufl., Bd III. Berlin, 1958, pp. 4359.

[40] R.R. Galeev, S.Kh. Vyshegurov, V.S. Demshina, M.S. Shulga, M.A. Gumel, Efficiency of regenerating potato varieties by the apical meristem method. Journal of Pharmaceutical Sciences and Research. 2018. vol. 10. no. 1 , pp. $124-128$. 